\title{
АГРАРНАЯ ПОЛИТИКА В СТРАНАХ С РАЗВИВАЮЩЕЙСЯ ЭКОНОМИКОЙ: ВЫБОР ИНСТИТУЦИОНАЛЬНОГО НАПРАВЛЕНИЯ
}

\author{
(C) 2018 Осипов Владимир Сергеевич \\ доктор экономических наук \\ Московский государственный институт международных отношений (университет) \\ Министерства иностранных дел Российской Федерации (МГИМО) \\ 119454, г. Москва, проспект Вернадского, 76 \\ E-mail:vs.ossipov@gmail.com
}

В статье предпринята попытка поиска дисфункций в реализации институциональных реформ в агропродовольственном секторе стран с развивающейся экономикой. На основе институционального анализа выявлены два направления институциональных реформ - пигувианское и коузианское,- по именам выдающихся теоретиков институциональной науки (А. Пигу и Р. Коуз). Показано различение этих направлений и возможные направления реализации направлений в аграрной сфере. Выявлена проблема доверия в аграрной экономике. Восстановление доверия показывается как основополагающая проблема в реализации институциональных реформах в аграрном секторе экономики стран с развивающейся экономикой.

Ключевые слова: институциональная реформа, коузианское и пигувианское направление институциональных реформ, доверие, аграрный рынок, инфраструктура.

Шанхайская организация сотрудничества преследует цель обеспечить экономическое развитие стран-участниц. Аграрная политика занимает одно из ведущих мест в обеспечении интенсивных консультаций между странами-участницами ШОС и представляет собой составную часть государственной социально-экономической политики, направленной на устойчивое развитие сельского хозяйства и сельских территорий. Так как аграрная политика - это часть государственной социально-экономической политики, то она должна подчиняться общим принципам формирования последней. Понимание того факта, что аграрная политика выражается в стратегии повышения эффективности аграрного производства, что, в свою очередь, требует обеспечения защиты экономических интересов сельскохозяйственных товаропроизводителей от антиконкурентного поведения зарубежных аграриев, позволяет нам определить институциональные направления реализации аграрной политики. Важно отметить, что для всех стран с развивающейся экономикой наблюдаются сходные проблемы в реализации государственной аграрной политики [11].

Принципы аграрной политики сводятся к последовательности осуществления мер государственной аграрной политики, институционализации и адресности государственной поддержки, формированию цивилизованных рыночных условий на рынке аграрных продуктов, открытости аграрной политики. Основными направлениями аграрной политики следует назвать защиту интересов отечественных сельскохозяйственных товаропроизводителей и формирование институциональных условий устойчивого развития аграрной сферы, что следует из нормативного определения аграрной политики.

Интересы российских сельхозтоваропроизводителей получили особую институциональную поддержку в связи с введением запретительных мер в рамках политики импортозамещения. Новые институты создали новые условия для расширения производства аграрных продуктов

Следует отметить, что основная проблема в системе государственного управления экономическими отношениями раскрывается через дихотомию стремления к упорядоченности и предсказуемости отношений и поведения акторов, и необходимости постоянного развития посредством внесения изменений в отношения и поведение акторов. Выстраивание системы государственного управления подчиняется цели решения указанной дихотомии через поиск баланса разумного консерватизма и необходимого динамизма.

Пигувианское направление экономической политики предусматривает формирование такой системы институтов государственного 
управления, которая вынуждает акторов действовать в соответствии с интересами инициатора института. Инициатор института (государство) в этом случае принимает на себя роль координатора потребностей общества. Коузианское направление, напротив, предлагает решение трех проблем институционализации экономики: развития конкуренции, защиты прав собственности, минимизации трансакционных издержек. Предполагается, что акторы будут самостоятельно действовать эффективно в интересах как инициатора института, так и общества в целом. Важной проблемой остается выбор пути институциональных реформ.

Коузианское направление институциональной реформы оказывается более предпочтительным по сравнению с пигувианским из-за возможностей большей симметрии в распределении информации относительно импортируемого института.

В нашем случае реализация институциональной реформы в аграрной сфере начиналась (в 1992 г.) с формирования и укрепления частной собственности, снижения монополизма для развития конкуренции и минимизации трансакционных издержек, тем не менее, со временем свернула с коузианского направления в пигувианское. Институциональная реформа стала преследовать цель формирования такого хозяйственного механизма, который был бы наиболее податлив к политическому влиянию. Политическая целесообразность стала диктовать направление экономического развития, а значит и руководящие указания системы государственного управления были переориентированы не на триединые коузианские условия, а на пигувианскую подверженность политическим решениям.

Методология исторического институционализма позволяет нам оценить повторяемость процессов монополизации в сельском хозяйстве. А.В. Чаянов отмечал: «Повторяя этапы развития промышленного капитализма, сельское хозяйство, выходя из форм полунатурального бытия, попадает под власть торгового капитализма, который подчас в форме весьма крупных торговых предприятий вовлекает в сферу своего влияния массы распыленных крестьянских хозяйств и, овладев связями этих мелких товаропроизводителей с рынком, хозяйственно подчиняет их своему влиянию и, развивая систему кабального кредита, превращает организацию сельскохо- зяйственного производства чуть ли не в особый вид раздаточной конторы, построенной на «системе выжимания пота»» [2].

В новейшей истории наблюдается приблизительно такая же картина. Сельскохозяйственные товаропроизводители зачастую предпочитают сбывать продукцию «с поля». Несмотря на то, что права собственности оказались тем или иным образом реализованы, либо через имущественные паи и земельные доли при приватизации колхозов и совхозов, либо через прямую покупку земли и средств производства на свободном рынке, проблема монополизма и высоких транзакционных издержек не позволили сформировать самоорганизующуюся инфраструктуру рынка, в которой сельхозтоваропроизводители могли бы свободно и прибыльно сбывать свою продукцию, а покупатели получать высококачественные продукты питания. Почему так происходит? Сельхозтоваропроизводители и потребители их продуктов находятся на довольно больших расстояниях друг от друга, а также во времени, сырье и полуфабрикаты проходят несколько операций производственного процесса до получения готового продукта. Инфраструктура рынка изменилась существенно, добавились новые участники воспроизводственного процесса, но одна проблема осталась в прежнем состоянии - уровень трансакционных издержек для сельскохозяйственного товаропроизводителя остался довольно высоким, что не позволяет им играть роль активного участника продовольственного рынка. Высокий уровень транзакционных издержек объясняется двумя причинами: географической и временной разобщенностью производителя и потребителя, что приводит к транспортным издержкам, а также к издержкам хранения, но при этом, играют роль затраты на организацию каналов сбыта - оптовую торговлю и розничный бизнес. Кроме того, важное значение имеет переработка сельскохозяйственного сырья и упаковка продукта. В сумме эти затраты оказываются неподъемными для сельскохозяйственного товаропроизводителя, что заставляет его принимать пассивное участие в воспроизводственном процессе и сбывать продукцию «с поля» по довольно низкой цене. Правильно отмечает исследователь Э.В.Эрдниева: «У сельскохозяйственного товаропроизводителя есть выбор путей реализации своих товаров. Если он продает продукты прямо потребителю, он может получить хорошую цену, но должен 
тратить время и прикладывать усилия (вложить труд) для их сбыта, одновременно осуществлять производство на предприятии. Другой путь продукта - «от ворот фермы»: его покупают посредники, которые выполняют функции хранения, транспортировки, подработки и переработки, упаковки в нужное время и в нужном потребителю месте» [3].

Эффективность сбыта сельскохозяйственного сырья и продуктов, таким образом, определяет, насколько сельское хозяйство интегрировано в воспроизводственный процесс. Если сбыт получает большую долю прибыли от продажи готовых продуктов, значит роль сельскохозяйственного производства как актора воспроизводственного процесса крайне слаба. В этой ситуации рыночная власть в большей степени оказывается в руках сбытового сектора, он и диктует условия функционирования рынков для всех остальных участников - как производителей сельскохозяйственного сырья и продуктов, так и конечных потребителей продуктов $[1,4]$.

В этих условиях от сбытовых фирм также зависит, какие цены формируются для производителя сырья и для потребителя конечного продукта при данном предложении и данном спросе на аграрные товары. В развитых странах сфера сбыта продовольствия довольно сильно развита и регулируется не только законами рынка, но и нормативными установлениями. Совершенно неверно предполагать, что законом можно установить цены на продукты, но можно сформировать для всех участников воспроизводственного процесса такие институциональные условия, что производство целесообразно во всех операциях воспроизводственного процесса. В настоящее время следует констатировать дисбаланс нормы прибыли в разных операциях воспроизводственного процесса, когда одни участники имеют очень высокий уровень, а другие - балансируют на грани рентабельности. Важно отметить, что такая ситуация не только ненормальна с точки зрения рыночных отношений, но и с позиций продовольственной безопасности, так как дисбаланс делает производство продуктов отечественного происхождения сложным и, как было еще совсем недавно, приводит к засилью импорта, так как сбытовые фирмы заинтересованы в гарантированных и крупных поставках, чего слаборазвитое сельское хозяйство предоставить не может.

Чаянов А.В. так описал сбытовой процесс сельскохозяйственных продуктов:

«В ходе изучения строения торгового аппарата для рынков сбыта различных сельскохозяйственных продуктов, мы можем отметить пять основных ступеней товарного пути сельскохозяйственных продуктов:

I. Распыленный по отдельным производителям товар собирается рядом скупщиков и прасолов и концентрируется в их руках.

II. Собранный скупщиками товар подвергается грубой сортировке и перевозится из мест сборки в местные центры оптовой торговли.

III. В оптовых центрах товар подвергается сортировке и распределению по направлениям дальнейшего движения.

IV. Собранный в центре и рассортированный товар перевозится в местные потребительские оптовые центры.

V. Из местных оптовых центров товар с помощью торгового распределительного аппарата (местных лавочников и других торговцев) поступает к распределителю».

За исключением некоторых особенностей и современных технологий, архитектура аграрного рынка слабо изменилась за почти вековую историю.

Это свидетельство укорененности такого института сбыта для аграрного рынка. Значит, существуют силы, которые поддерживают такую структуру рынка и уровень рыночной власти участников воспроизводственного процесса. Нельзя такую структуру признать эффективной из-за дисбаланса интересов и нормы прибыли среди участников воспроизводственного процесса. Хотя дисбаланс нормы прибыли в операциях внутри цепочки ценности характерен для любого производственного процесса [9], тем не менее, именно в аграрной сфере и продовольственном обеспечении он наиболее чувствителен для потребителей и производителей сельскохозяйственного сырья.

Как мы отмечали ранее, нормативное установление процесса ценообразования взамен рыночного недопустимо, так как подорвет эффективность всего воспроизводственного процесса, снизит налогооблагаемую базу, поэтому следует направить усилия к поиску институтов, способных опосредованно оказать влияние на процесс распределения прибыли внутри цепочки ценности от получения сырья до доведения готового продукта до конечного потребителя.

Опосредованное влияние может быть оказа- 
но путем усиления рыночной власти наиболее слабого участника воспроизводственного процесса - производителей сельскохозяйственного сырья и первичных продуктов [10,13].

Следует отметить, что в целях повышения эффективности колхозов, их подвергли реструктуризации и деколлективизации, в результате чего, по замыслу реформаторов, должен был образоваться слой эффективных фермеров - производителей сельскохозяйственных продуктов [12]. Авторы при этом делают важную оговорку: «Осуществление приватизационных программ необязательно способствует повышению эффективности хозяйствования». Главное заблуждение кроется в убеждении, что экономика капиталистического рынка возникнет спонтанно, как только утвердится частная собственность, введены свободные цены, осуществлена стабилизация денежной системы, созданы нерегулируемые, основанные на конкуренции рынки [7].

Германский опыт показывает вариант решения проблемы, когда сельхозтоваропроизводители - фермеры, как наиболее слабые участники воспроизводственного процесса, смогли усилить свою роль путем формирования кооперативов. Операции воспроизводственного процесса, которые характеризуются объединением потоков материальных ресурсов, могут быть переданы на исполнение кооперативам, участие в которых сельскохозяйственных товаропроизводителей позволяет им получить большую рыночную власть за счет обеспечения больших объемов стандартизированной продукции в понятные и прогнозируемые сроки. Так, баварские фермеры получают от кооперативов семенной материал, удобрения, технику, молодняк для выращивания и т.д., осуществляют производственный процесс в строгом соответствии с технологией, контроль за исполнением которой осуществляют специалисты кооператива. В определенные сроки фермеры сдают продукцию кооперативу, который обеспечивает не только сбор, но и переработку сырья на собственных перерабатывающих заводах. Кооперативы позволяют фермерам усилить свою рыночную власть за счет участия в управлении соседними операциями производственного процесса. Некоторые кооперативы оказываются основными акционерами перерабатывающих предприятий и торговых сетей, что усиливает их рыночную власть еще более, а процесс распределения прибыли делает более справедливым и интересным для производителей сель- скохозяйственного сырья. Следует оговориться, что европейская аграрная политика базируется на дотациях к ценам производителя за выполнение доведенной производственной программы, однако, для нашего случая этим основанием можно пренебречь, так как нас интересует лишь институциональная структура, позволяющая достичь более сбалансированного распределения прибыли между участниками воспроизводственного процесса.

Такая модель взаимоотношений участников воспроизводственного процесса в аграрной сфере была бы вполне применимой и для рынков стран ШОС, если бы не одно ограничение - низкий уровень доверия акторов друг к другу. Может показаться, что это чисто российская проблема, однако, это не так. Британский историк Дж. Хоскинг отмечает: «Западный мир переживает кризис доверия» [6]. Он говорит об утрате доверия граждан к своим государствам. Объяснение этого явления выходит за рамки нашего исследования, поэтому мы не будем его касаться, но лишь примем как данность [5]. Таким образом, доверие оказывается краеугольным камнем для усиления роли слабых участников аграрного рынка для выравнивания и более справедливого баланса прибыли и обеспечения продовольственной безопасности. Профессор Р. Локке утверждает: «Доверие можно создать! [8]». Формирование доверия в аграрной сфере вполне возможно, хотя на первый взгляд, и не совсем ясен путь достижения. Мы постараемся сформировать направление повышения доверия для аграрного рынка.

Базовой ступенью механизма повышения доверия в аграрном рынке выступает заинтересованность акторов. Без заинтересованности акторов в повышении доверия невозможно двигаться дальше. Доверие может стать интересным в том случае, если институциональные основания в аграрном рынке окажутся стабильными, в чем должно проявить свою заинтересованность государство и его органы, отвечающие за реализацию аграрной политики, а в более широком плане - органы, отвечающие за экономическую политику. Акторы довольно быстро откликнутся на стабилизацию институциональных условий расширением деловой активности, инвестиций и капитальных вложений. Вторая ступень механизма оказывается реализованной посредством активной роли политики государства в реализации институциональных реформ. Здесь 
наиболее востребованными окажутся проекты государственно-частного партнерства, доказавшие свою эффективность в инфраструктурных проектах. Поощрение кооперации и самоуправления (хотя бы на примере немецких союзов производителей различных видов сельскохозяйственных продуктов), а также выдвижение их инициатив на первый план в процессе выработки институциональных условий аграрного рынка, по сути, будет способствовать выравниванию правил поведения на рынке и самоконтроля.
Высшей точкой механизма повышения доверия для аграрного рынка выступает инфраструктура. Мы имеем в виду инфраструктуру рынка аграрных продуктов, которая формируется при условии доверия акторов по отношению друг к другу. Подрыв доверия должен наказываться исключением сельскохозяйственного товаропроизводителя из союза, широким распространением информации о недобросовестном его поведении на рынке и рисках взаимодействия с таким актором.

\section{Библиографический список}

1. BogovizA.V., Bugai Y.A., Osipov V.S. Import substitution in the agro-industrial complex in the interests of provision of food security: Option or necessity?// Advances in Intelligent Systems and Computing. 2018. 622. Pp. 37-43.

2. Chayanov A. The Theory of Peasant Economy. // The American Economic Association. 1966.

3. Эрдниева Э.В. Некоторые проблемы сбыта сельскохозяйственной продукции // Экономика и предпринимательство. 2014. № 11-3 (52-3). С. 407-409.

4. Gulyayeva T.I., Kuznetsova T.M., Gnezdova J.V., Veselovsky M.Y., Avarskii N.D. Investing in innovation projects in Russia’s agrifood complex // Journal of Internet Banking and Commerce. 2016. \#21 (Special Issue \#6).

5. Hosking G. Trust: Money, Markets and Society. 2010. Seagull Books.

6. Hosking G. Trust: a History. Oxford. 2014. Oxford University Press.

7. Kregel J., Matzner E., Graber G. Market shock. International Institute of the World. 1992. P.126.

8. Locke R. Building Trust //Paper presented at the Annual Meetings of the American Political Science Association. San Francisco. 2001.

9. Осипов В.С. Направления аграрной и промышленной политик России: от санкций к конкурентоспособному импортозамещению // Никоновские чтения. 2016. № 21. С. 113-115.

10. Евсеев В.О., Скрыль Т.В., Шавина Е.В., Осипов В.С., Невская Н.А. Промышленная политика России: политэкономические и региональные аспекты. Москва, Сер. Научная книга. 2016.

11. Silvestrov S.N., Zeldner A. G., Osipov V.S. Introduction to the Theory of Economic Dysfunction // Mediterranean Journal of Social Sciences. 2015. Vol. 6. \#3. Pp. 394-399.

12. Tillack P., Schultze E. Institutional problems of agricultural production. Agrifood complex of Russia on the market way // Analytical center of agrifood economics, Institute of transition economics. (2001).

13. Зельднер А.Г. Инвестиции как условие экономического роста АПК // Международный сельскохозяйственный журнал. 2005. № 5. С. 19-20. 